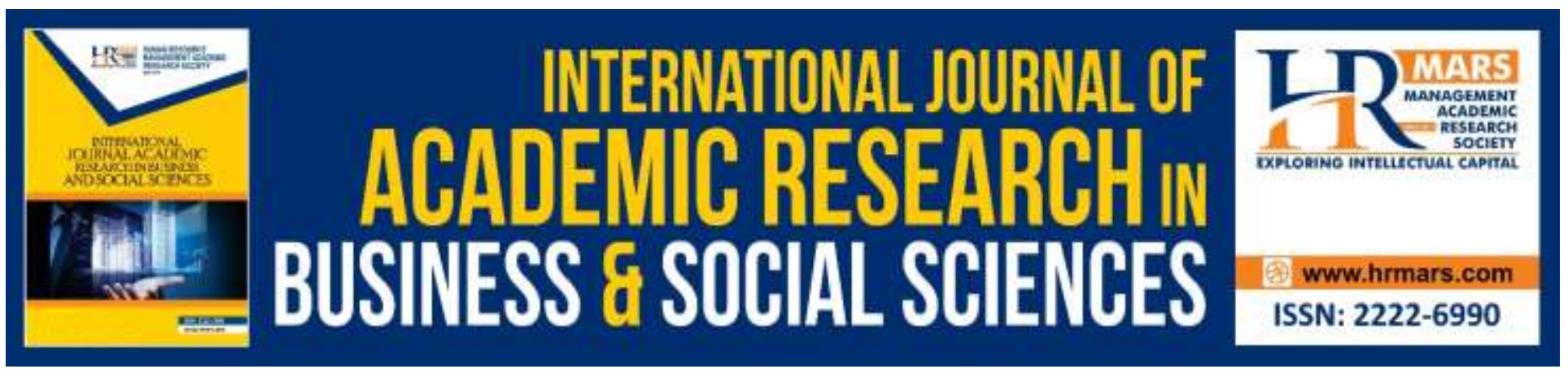

\title{
A Qualitative Analysis on Causes of Human Trafficking from the Perspective of Malaysian Authorities
}

\author{
Nurul Amirah Hamzah, Nooraini Othman, Wardatul Aishah Musa
}

To Link this Article: http://dx.doi.org/10.6007/IJARBSS/v10-i3/7025

DOI:10.6007/IJARBSS/v10-i3/7025

Received: 21 January 2020, Revised: 06 February 2020, Accepted: 24 February 2020

Published Online: 23 March 2020

In-Text Citation: (Hamzah et al., 2020)

To Cite this Article: Hamzah, N. A., Othman, N., \& Musa, W. A. (2020). A Qualitative Analysis on Causes of Human Trafficking from the Perspective of Malaysian Authorities. International Journal of Academic Research in Business and Social Sciences, 10(3), 77-90.

Copyright: (C) 2020 The Author(s)

Published by Human Resource Management Academic Research Society (www.hrmars.com)

This article is published under the Creative Commons Attribution (CC BY 4.0) license. Anyone may reproduce, distribute, translate and create derivative works of this article (for both commercial and non-commercial purposes), subject to full attribution to the original publication and authors. The full terms of this license may be seen

at: http://creativecommons.org/licences/by/4.0/legalcode

Vol. 10, No. 3, 2020, Pg. 77 - 90

http://hrmars.com/index.php/pages/detail/IJARBSS

JOURNAL HOMEPAGE

Full Terms \& Conditions of access and use can be found at http://hrmars.com/index.php/pages/detail/publication-ethics 


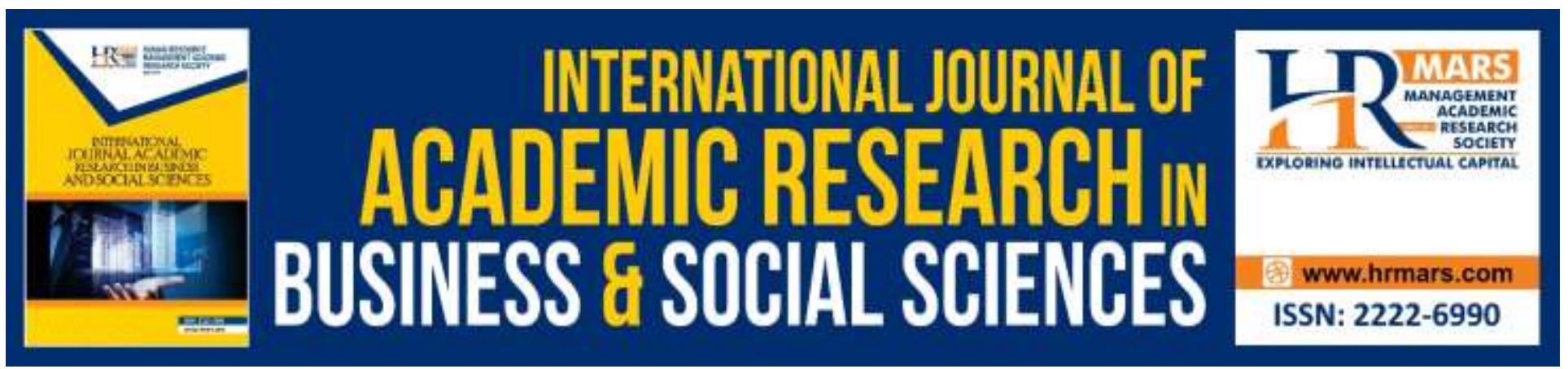

\title{
A Qualitative Analysis on Causes of Human Trafficking from the Perspective of Malaysian Authorities
}

\author{
Nurul Amirah Hamzah, Nooraini Othman \\ Perdana Centre of Science, Technology \& Innovation Policy, Razak Faculty of Technology and \\ Informatics, Universiti Teknologi Malaysia \\ Email: amirahhamzah94@gmail.com,p-noraini@utm.my
}

\author{
Wardatul Aishah Musa \\ Universiti Kuala Lumpur \\ Email: wardatulaishah@unikl.edu.my
}

\begin{abstract}
Human trafficking is an issue prevalent in most countries including Malaysia.This article aims to discuss the findings of a qualitative analysis on the causes of human trafficking in Malaysia.The study involves data collection, in-depth interviews with five informants among the authorities involved directly in dealing with human trafficking. Based on the findings from the interviews conducted, there are several causes of human trafficking in Malaysia. Among these are human attitudinal weaknesses, the presence of demand and outsourcing companies and foreign employment agencies.

Keywords: Human Trafficking, Causes, Human Weaknesses, Malaysia, Qualitative Analysis

\section{Introduction}

Human trafficking is a current trend of criminal behaviour as well as a social problem that has a negative impact on a society as well as a country's development (Norcikeyonn and Nor-Ina, 2013). According to the United Nations (2000) human trafficking is defined as an act involving the procurement or retention of a person's labour or service through coercion such as recruiting, transporting, transferring, obtaining, providing or receipt of someone for the purpose of exploitation. Exploitation is any form of sex exploitation, work or forced service, slavery or practices that resemble slavery, any unlawful activity or displacement of human organs.
\end{abstract}


INTERNATIONAL JOURNAL OF ACADEMIC RESEARCH IN BUSINESS AND SOCIAL SCIENCES Vol. 10, No. 3, March, 2020, E-ISSN: 2222-6990 @ 2020 HRMARS

There are three important elements that are used throughout the world in determining that human trafficking has taken place (A Bali Process, 2015). These elements are activities, methods and purposes. Elements of activity include recruitment, transportation, displacement, protection, and harbouring of victims. Elements of methods include threats, coercion or violence, displacement, manipulation, forgery of documents, abduction, fraud, abuse of power, giving or receiving payments and purpose elements include sexual exploitation or prostitution, slavery, bondage, organ displacement and forced labour or services.

Human trafficking is carried out via three methods or routes through which the three methods or routes are by air, sea and land (Habibah, 2011). One of these three routes is used to ferry human trafficking victims from the source country which is the country from which the victims originate to a transit country and the destination countries. A transit country is a country used as a route to bring human trafficking victims before they reach their destination country. The destination country is the recipient country or the last country that receives human trafficking victims.

In general, almost all countries in the world are involved in human trafficking (Halim, 2015). Malaysia is also one of those countries that has to deal with human trafficking issues.

According to a report on human trafficking issued by the United States Department of State, since 2006 Malaysia has been identified as a transit country and also a destination for trafficking victims comprising mainly women from China, Indonesia, Thailand, the Philippines and Vietnam (US Department of State, 2006). These victims are mostly exploited as sex workers. In addition to women, there are also victims of human trafficking comprising foreign men who are mostly exploited as forced labourers.

One of the important aspects to be considered in the issue of human trafficking in Malaysia is the root cause of the issue. The cause is the basis or origin of a matter and an issue. In this study, the cause is referred to as the basis for human trafficking. The cause of human trafficking is the source at the early stage that triggers the issue. In Malaysia, not much research has been conducted on the causes of human trafficking. As this is a qualitative research, the research focused on an in-depth study about the causes of human trafficking and to differentiate between the meaning of the causes and the influencing factors. Previous studies showed that causes and factors are pointing to the same element whereas the findings of this research proved otherwise. This study did not try to support any theories on human trafficking instead it successfully highlighted that Maslow's Theory of Needs helps to explain on the issue of human attitude in fulfilling their needs. In this case, human trafficking issues were caused by the weaknesses of human attitude in dealing with several aspects of individual life.

Thus, it is important to identify the causes of human trafficking in Malaysia so that effective measures to address this issue can be taken by the responsible parties. In this study, the causes of human trafficking in Malaysia are identified through interviews conducted with authorities involved in dealing with this issue 
INTERNATIONAL JOURNAL OF ACADEMIC RESEARCH IN BUSINESS AND SOCIAL SCIENCES

Vol. 10, No. 3, March, 2020, E-ISSN: 2222-6990 C 2020 HRMARS

\section{Research Design}

The design of a study is the strategic plan to identify the methods and procedures for collecting and analysing what the study requires (Zikmund, 2013). For researchers, the design of the study refers to the guidelines, plans or strategies that describe the procedures used to obtain an answer to each research question. Qualitative studies are chosen since natural approaches are used to understand the phenomena in specific contexts. This method provides an understanding of the true state of the phenomenon and the context of the study without manipulating any real situation (Patton, 2015). Case studies based on interviews with the authorities and non-governmental bodies are conducted for the purpose of its data collection.

\section{Sample and Sampling Techniques of the Study}

The study sample is a group or group subset specifically selected to represent the population in a study. Selecting a study sample is an important step in any research in order to obtain reliable data. In this study, the sample comprises the authorities involved in the issue of human trafficking in Malaysia. The sampling technique used is the purposive sampling. Several criteria have been put in place to assist in the selection of the study sample as the technique used is objective sampling. Sample size is determined by the achievement of data saturation level. Data analysis is carried out after each interview to ensure sufficiency and the sufficient level of data is achieved at the end of the data collection process. The lists of selected samples, sample codes, sample counts involved in the study and selection criteria are as shown in Table 1 below:

\begin{tabular}{|c|c|c|c|c|}
\hline & Selected Samples & $\begin{array}{l}\text { Sample } \\
\text { Code }\end{array}$ & $\begin{array}{l}\text { Number } \\
\text { of } \\
\text { Sample } \\
\text { (Persons) }\end{array}$ & $\begin{array}{c}\text { Sample Selection } \\
\text { Criteria }\end{array}$ \\
\hline \multirow[b]{4}{*}{$\begin{array}{l}\text { The } \\
\text { Authorities }\end{array}$} & $\begin{array}{l}\text { The Royal } \\
\text { Malaysian Police }\end{array}$ & PBI & $\begin{array}{l}1 \\
1\end{array}$ & \multirow{4}{*}{$\begin{array}{l}\text { - Authorities } \\
\text { involved in } \\
\text { human } \\
\text { trafficking } \\
\text { issues in } \\
\text { Malaysia } \\
\text { - Member of } \\
\text { the Anti- } \\
\text { Trafficking in } \\
\text { Persons and } \\
\text { Anti- } \\
\text { Smuggling of } \\
\text { Migrants }\end{array}$} \\
\hline & $\begin{array}{l}\text { Department of } \\
\text { Labour, Peninsular } \\
\text { Malaysia }\end{array}$ & PB2 & 1 & \\
\hline & $\begin{array}{l}\text { The Immigration } \\
\text { Department }\end{array}$ & $\begin{array}{l}\text { PB3 } \\
\text { PB3 }\end{array}$ & 1 & \\
\hline & $\begin{array}{l}\text { The Royal } \\
\text { Malaysian Customs } \\
\text { Department }\end{array}$ & PB4 & 1 & \\
\hline
\end{tabular}


INTERNATIONAL JOURNAL OF ACADEMIC RESEARCH IN BUSINESS AND SOCIAL SCIENCES Vol. 10, No. 3, March, 2020, E-ISSN: 2222-6990 @ 2020 HRMARS

\begin{tabular}{|c|c|c|c|}
\hline & & & $\begin{array}{l}\text { Council } \\
\text { (MAPO) }\end{array}$ \\
\hline $\begin{array}{l}\text { Secretariat of the } \\
\text { Anti-Trafficking in } \\
\text { Person and Anti- } \\
\text { Smuggling of } \\
\text { Migrants Council } \\
\text { (MAPO) }\end{array}$ & PB5 & 1 & $\begin{array}{l}\text { - Authorities } \\
\text { involved in } \\
\text { human } \\
\text { trafficking } \\
\text { issues in } \\
\text { Malaysia } \\
\text { - Implement } \\
\text { and } \\
\text { coordinate } \\
\text { policies and } \\
\text { programs on } \\
\text { human } \\
\text { trafficking and } \\
\text { trafficking } \\
\text { issues in } \\
\text { Malaysia }\end{array}$ \\
\hline
\end{tabular}

Table 1: Selected Samples, Sample Codes, Sample Count and Selection Criteria

\section{Data Analysis Method}

This study uses thematic analysis method in analysing the data. The thematic analysis method is one of the most widely used research methods in qualitative research. Thematic analysis is an analytical approach based on or characterised by certain themes. According to Braun and Clarke (2006), there are six processes used to analyse data using thematic methods:

i) Collect and understand data

ii) Generate initial coding

iii) Find themes

iv) Create theme highlights

v) Refine theme categorization

vi) Generate a report

The first process requires researchers to collect data. The data are collected by the researchers through interviews conducted with the parties involved. For the purpose of data collection, the researchers record all interview sessions conducted using a recorder. The researcher then transcribes the data. Transcripts are imperative to carry out because through transcriptions, researchers can better understand the data collected. A transcript is performed each time an interview is completed 
INTERNATIONAL JOURNAL OF ACADEMIC RESEARCH IN BUSINESS AND SOCIAL SCIENCES

Vol. 10, No. 3, March, 2020, E-ISSN: 2222-6990 @ 2020 HRMARS

so that the data analysis process could be carried out until data saturation is reached and the sample size could be determined when all the findings have answered the research questions.

The second process is to generate the initial coding. The initial coding process begins when the researcher has read, understood and listed the key points of the transcribed data. This is important for generating initial coding. The initial coding is generated by the researcher manually by writing the code on the transcribed data. Once the initial coding has been generated, the researcher carries out the third process; the search for themes.

Finding themes is an important process. This process is a process that requires researchers to perform more detailed analyses to identify the themes involved. After the themes are identified, the researchers incorporate the codes obtained during the initial coding process into those themes. To facilitate researchers to incorporate the codes obtained during the initial coding process into predefined themes, researchers use mind maps to represent each theme as suggested by Braun and Clarke (2006).

Next is the process of creating theme highlights. This process is important to determine whether the themes that the researcher has chosen during the search process are the right ones. In the process of highlighting themes, researchers need to make sure the themes selected are proven through the data obtained. If the selected theme cannot be supported by the data obtained, then it is not the right theme. Through this process, researchers are able to identify themes that can be incorporated and that there are also themes that need to be separated (Patton, 1990).

After the theme highlighting process, the researcher goes through the process of refining the theme categorisation. The process of refining theme categorisation is important for the reason that through this process researchers can refine the themes selected during the process of highlighting the theme in more detail. Researchers can determine whether the selected theme is a standalone theme or needs to be broken down into sub-themes (Braun and Clarke, 2006). At the end of this process, every selected theme is named with the most appropriate names before writing the report.

\section{Findings and Discussion}

\section{The Beginning of Human Trafficking Issues in Malaysia}

The analysis of the findings of the study show that several causes have contributed to the issue of human trafficking in Malaysia. The causes are:

\section{Weaknesses of Human Attitudes}

Human weakness is seen as one of the main causes of human trafficking in Malaysia. This weakness of human behaviour includes the attitudes of irresponsible parties who trafficking in the same manner as employers to employees. The weakness of this irresponsible party is noticeable when they cannot control themselves in the interests of exploiting other people and hence, human trafficking. This is stated by the authorities when interviewed by the researchers.

"The cause of human trafficking is due to the weakness in the human behaviour. They choose to exploit others for their own selfishness." (PB5) 
INTERNATIONAL JOURNAL OF ACADEMIC RESEARCH IN BUSINESS AND SOCIAL SCIENCES Vol. 10, No. 3, March, 2020, E-ISSN: 2222-6990 (C) 2020 HRMARS

"Human behavior can be the cause of human trafficking. Why choose to sell people? Because they want attain what they want in an easy way." (PB3)

"What matters most is the attitude of the employer. Why would one choose to be involved in human trafficking such as forced labour? It is because he is greedy." (PB2)

Based on interviews conducted with the authorities, the researchers find that the weakness of both the employer and the individual involved in the human trafficking issue in Malaysia is mainly due to their interest in making a huge profit. For employers, most of them are involved in human trafficking issues, especially using forced labourers as their work force. The use of forced labour can reduce employers' costs in terms of labour management compared to if the employer employs legitimate workers.

In addition, employers do not have to pay high wages if they employ forced labour and these forced workers may be forced to work overtime at any time without pay. As such, some irresponsible employers decide that the use of forced labour is the easiest way to obtain cheap labour while earning a greater profit and it is this attitude that causes human trafficking as stated by some of the authorities interviewed.

"This employer is really greedy. His attitude is to make a huge profit. Instead of hiring legitimate workers and he has to pay overtime and has to spend a lot of capital, it's better to get forced labor. From one angle, employers take the easy way out for making profit." (PB2)

"Examples are like forced labourers. The employer thinks this forced labourers are cheap. If we choose this way instead of hiring legitimate workers, it will cost a lot of money. "(PB4)

"From the employers' point of view, their attitude is to simply take advantage, exploit people for what reason? For making profit. "(PB5)

Based on previous studies especially in Malaysia, there are not many studies that explicitly address the real cause for human trafficking in the country. In fact, human weakness and the irresponsible attitude of traffickers in exploiting others for their own benefits, have not been highlighted in any previous research, especially in local research, as the leading cause of human trafficking in Malaysia

This finding is consistent with the opinion of Richmond (2017), the Head of Department of the United States Department of State that monitors and combats human trafficking. He pointed out that weaknesses in irresponsible human behaviour is actually a major cause of human trafficking. This is because according to him, an individual always has the choice whether to engage in this issue or not but there are some weak and uncontrollable individuals who choose to engage in human trafficking on the basis of pursuing their own self-interests. 
INTERNATIONAL JOURNAL OF ACADEMIC RESEARCH IN BUSINESS AND SOCIAL SCIENCES

Vol. 10, No. 3, March, 2020, E-ISSN: 2222-6990 C 2020 HRMARS

\section{Existing Demands}

The findings also show that there are other causes of human trafficking in Malaysia. One such reason being the particular demand for forced labourers and sex workers such as prostitutes. The demand for forced labour is usually from employers who require large numbers of workers and low wages as mentioned by the authorities interviewed for this research.

"The main cause is demand. The demand for cheap labour ...doesn't matter to the sex industry or to what industry. Industries have demands for workers. "(PB3)

"There is a great demand for victims of human trafficking especially as forced labourers."

"With the current situation, employers are all about reducing costs. Want more profits. With forced labour, costs are lower. This is the fact that we have to accept." "(PB2)

For some employers, the use of forced labour services is a shortcut to greater profits because by employing forced labour, employers actually reduce costs in terms of payroll and maintenance matters. At the same time, the economic downturn of the Malaysian economy also attracts foreigners who live in bad conditions in their country to work in this country and this opportunity is used by employers to exploit foreigners for forced labour. as stated by the authority interviewed in this study.

"The reason is the demand. Economic growth has lured people out there in Vietnam, China and other resource countries to come to Malaysia to work here. In Malaysia they are being exploited as sex workers and forced labourers. "(PB1)

"So, when the victims themselves are poor, then there is the opportunity that gives them the chance to work, the victims agree and that's how they become victims of human trafficking." (PB2)

Apart from the increasing demand for forced labour, the demand for the services of sex workers such as prostitutes is also high in Malaysia. Large numbers of foreigner girls especially girls from foreign countries such as Indonesia, Thailand, Vietnam, Philippines, China and Myanmar have been brought to Malaysia for exploitation as prostitutes. According to authorities interviewed by the researchers, prostitution services are in high demand in certain regions, especially in developed countries.

"The demand for prostitutes is high in states like Johor, Kuala Lumpur, Selangor and Penang. This is because of the progress in these states. "(PB3)

"Sexual exploitation occurs because there is demand in a places that requires sexual services. So there will be those who provide the service. "(PB5). 
INTERNATIONAL JOURNAL OF ACADEMIC RESEARCH IN BUSINESS AND SOCIAL SCIENCES Vol. 10, No. 3, March, 2020, E-ISSN: 2222-6990 ¿ 2020 HRMARS

The demand for prostitutes usually comes from individuals as well as prostitution syndicates Not only that, the demand for prostitutes also come from foreigners working in the country. This is acknowledged by the authorities who are interviewed by the researchers.

"Many Bangladeshi workers are here. They want to have fun at night. When it comes to having fun, it's with women, prostitutes. So there is a high demand for prostitutes. "(PB1)

Based on interviews conducted with the authorities, foreign girls who are exploited as prostitutes are often lured by other job offers in Malaysia, but when they arrive in the country they are deceived and forced into prostitution. There are also some who have been forced into prostitution and are not paid by prostitute ring lords.

"Sometimes some girls have to be prostitutes but all the money goes to for the employers. Sometimes, they are given a meagre amount a day. "(PB2)

"Many victims do not know they will be prostitutes. At first, they are told that they are going to be special escorts but they end up being whipped here. "(PB3)

In addition to being tricked into prostitution, some of the girls who tried to escape are coerced and abused by their employers. This coercion forces them to follow the instructions of the employers thus, the employer continues to exploit them.

The findings of this study are parallel to the findings of Norraiha (2016) which point out that human trafficking occurs in Malaysia as it is in high demand especially in the agricultural, industrial and services sectors. These sectors require a large and cheap labour force and hence, human trafficking victims are preferred to work in these sectors. Companies or organisations that use human trafficking victims for work can reduce costs thus earning higher profits. This results in a for human trafficking victims to become workers. Most recently, the Malaysian government, through the Home Minister Tan Sri Muhyiddin Yasin state that the demand from business communities is the reason for human trafficking issues going on in Malaysia (Sinar Harian, 5 August 2019).

\section{Outsource Companies and Foreign Employment Agencies}

Based on interviews conducted by the researchers with the authorities, outsourcing has been identified as one of the leading causes of human trafficking in Malaysia. This is because outsourcing companies are intermediaries who obtain contracts from employers to supply them with foreign workers. After these outsourcing companies supply these foreign workers to the employers, most of them pay little or no attention to their work situations and matters related to employee welfare. This leads to the high risk of foreign workers becoming victims of human trafficking in the form of forced labour.

"This outsourcing company is the cause. He supplies foreign workers to the employers, but after the supply, his hands are off. The welfare of the workers is not taken care of. 
INTERNATIONAL JOURNAL OF ACADEMIC RESEARCH IN BUSINESS AND SOCIAL SCIENCES

Vol. 10, No. 3, March, 2020, E-ISSN: 2222-6990 @ 2020 HRMARS

This is why these foreign workers are really exploited that they become forced labourers. "(PB1)

"The outsourcing company supplies foreign workers to the company. He should take care of the welfare of the foreign workers. Look into what kind of work it is, what kind of benefits, what about their work leave or holidays. Not to leave them on their own. And this is why they are being exploited by the employers. "(PB2)

"Most 'outsiders' are not aware that outsourcing companies are the root cause of this problem. They supply foreign workers but do not ensure that these workers are free from exploitation. Many incidence of forced labour occur because of this. "(PB3)

Foreign workers supplied by outsourcing companies are often exploited as forced labourers by the employers. Various forms of exploitation are imposed on them by employers who are mostly factory owners or plantation owners. Employers choose foreign workers as their labor force due to the need for large and cheap labour.

In addition to supplying foreign workers, there are also irresponsible outsourcing companies that sell their foreign workers to other employers. According to the authorities interviewed, the sale of foreign workers to other employers occurs when the outsourcing company no longer has a contract to supply foreign workers to the previous employer. The outsourcing company then sells these foreign workers to other parties such as business owners, plantation owners or other parties seeking foreign workers. After the sale takes place, these outsourcing companies will no longer be responsible for these foreign workers, especially in terms of work permits and payrolls. This makes it easier for foreign workers who are being sold to be exploited by their new employers. The matter is revealed to the researchers by the authorities interviewed.

"When the contract of an outsource company to supply foreign workers to a company ends, after which no other company offers a new contract, the outsource company usually sells these foreign workers to another party." (PB2)

"When an outsourcing company sells these foreign workers to another party, human trafficking takes place. There are cases of foreign workers who originally work on the estates being sold to car wash center operators. "(PB2)

"After selling to a new employer, the outsourcing company does not take any responsibilities anymore. No questions about expired permits or new employer does not pay wages. He is free. This makes it easy for new employers to exploit them and they become forced laborers again. "(PB3)

Apart from outsourcing companies, foreign employment agencies are also the cause of human trafficking in Malaysia. This is so as they act as intermediaries in the scouting of and hiring foreign workers on behalf of employers. Through interviews conducted with the authorities, these foreign 
INTERNATIONAL JOURNAL OF ACADEMIC RESEARCH IN BUSINESS AND SOCIAL SCIENCES Vol. 10, No. 3, March, 2020, E-ISSN: 2222-6990 ¿ 2020 HRMARS

workers are brought into the country legally while some are illegally brought in by foreign employment agencies to supply to employers. Most foreign workers who are illegally brought in do not have passports and work permits in Malaysia. This makes them vulnerable to exploitation by employers especially in the form of forced labour.

"Foreign employment agencies are behind this, too. They ask the factory management how many workers are needed then he brings foreign workers without passport, without permit. "(PB4)

"Just like outsourcing companies, foreign employment agencies supply foreign workers to employers. Some of them supply illegally. No permits and employers are happy to use them as forced labour. "(PB2)

As with foreign workers supplied by outsourcing companies, foreign workers supplied by foreign employment agencies face various forms of exploitation. They are often forced into labour in factories and on farms owned by the locals.

"Usually, the cases that have been brought to us involve foreigner who are brought in illegally by employment agencies and outsourcing companies. Then they are coerced into labour by employers at iron smelting factories, gloves factories and other kinds of factories. "(PB1)

"After an outsourcing company or employment agency supplies foreign workers to employers, they are forced to work in the plantation sector. Some of them come in proper way, with their passports but some do not." (PB1)

Foreign employment agencies mostly have agents to recruit foreign workers in other countries such as Indonesia, China and Vietnam, Bangladesh, India and Nepal. Foreign workers are recruited in their home countries with a variety of attractive job offers in Malaysia. However, the fact remains that after arriving in Malaysia, these foreign workers who have been recruited are handed over to employers who manipulate them into forced workers in their factories, farms or companies.

"Foreign employment agencies usually have agents for recruiting foreign workers in other countries like they have agents in Vietnam, they have agents in China, in India, Bangladesh, Nepal. Only then foreign workers can be brought to Malaysia. "(PB1)

"For example in Indonesia, in every district there are agents who recruit those who want to work in Malaysia. This agent then engages with a job agency in Malaysia. "(PB5)

"They have agents overseas. These agents go to the villages to meet the kids, fill in forms and offer jobs in Malaysia. Upon arrival in Malaysia, these foreign employment agencies take charge till workers are handed over to their new employers, then they become forced labourers. "(PB4) 
INTERNATIONAL JOURNAL OF ACADEMIC RESEARCH IN BUSINESS AND SOCIAL SCIENCES Vol. 10, No. 3, March, 2020, E-ISSN: 2222-6990 @ 2020 HRMARS

The existence of foreign outsourcing companies and foreign employment agencies has always been the root cause of human trafficking in Malaysia. This is acknowledged by almost all the authorities interviewed by the researchers. Although not all outsourcing companies and foreign employment agencies are involved in this issue, there are those who take advantage by supplying illegal foreign workers to employers for forced labour. As for outsourcing companies and foreign employment agencies that supply workers legally, the situation of the workers must be monitored to avoid the risk of exploitation, and to reduce the incidence of these workers to become forced labourers by their employers. The government also need to find effective solutions to enable outsourcing companies and foreign employment agencies to remain free of human trafficking issues.

The study conducted by the researchers also presents different findings from other studies as the findings of this study show that the presence of outsourcing companies and foreign employment agencies is one of the leading causes of human trafficking in Malaysia. The existence of foreign sourcing companies and foreign employment agencies has never been discussed as one of the leading causes of human trafficking in Malaysia in any previous study, especially local research. However, this is often discussed in reports of human trafficking in Malaysia issued by the US State Department (U.S. State Department, 2016). Based on the findings of the study, the existence of outsourcing companies is the cause of human trafficking in Malaysia especially in the form of forced labour. Outsourcing companies mostly focus on supplying the workforce to companies or organisations that need workers and not on the welfare of workers. This is supported by a report on human trafficking in 2018 which states that lack of oversight of outsourcing companies for the welfare of workers leads to higher exposure to those workers to be exploited as victims of human trafficking in the form of forced labour (U.S. State Department, 2018). The results are summarised as follows:

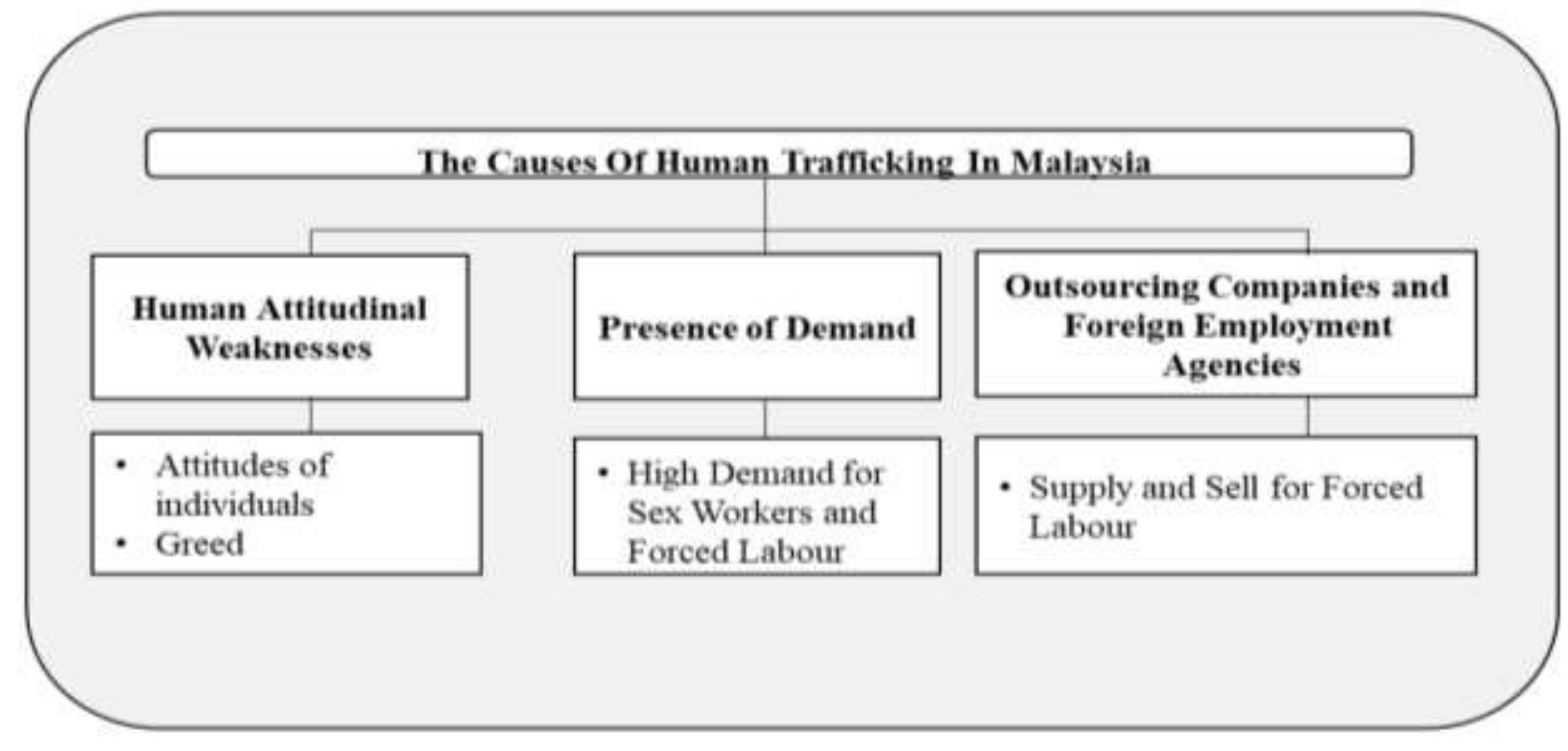

Figure 1 The causes of human trafficking in Malaysia 
INTERNATIONAL JOURNAL OF ACADEMIC RESEARCH IN BUSINESS AND SOCIAL SCIENCES Vol. 10, No. 3, March, 2020, E-ISSN: 2222-6990 @ 2020 HRMARS

\section{Conclusion}

Human trafficking is a complex issue that involves many parties. Weaknesses of the human behaviour make exploitation of human beings possible because of their greed and selfishness. This attitude also contributes to the growing demand for forced labour and sex workers which has opened avenues for greater profits at lower costs. The presence of demand and supply has led to the establishment of outsourcing companies which act as intermediaries in human trafficking activities.

Therefore, it can be concluded that there is a clear relationship between these three factors that builds a strong collaboration in the development of this issue. The responsibility to combat this issue begins with the individual construction of individuals. Creating a superior personality with a positive attitude can make people aware of the long-term implications of human trafficking issue. Of course, self-education needs to start from the home and continues to the next level of education built by the community itself. Social education can reduce social problems if all members of the community view this issue as a collective issue that will negatively impact everyone if it is not handled properly. The current policy relevant to human trafficking could be improved through a policy recommendation developed based on evidences provided by this research. Certain strategic goals could be focused on human development programs in developing strong resilience, dignified and positive individuals.

\section{Acknowledgement}

This research was executed for FRGS grant (Ref: FRGS/1/2017/SS06/UNIKL/03/1) titled Cause and Factors of Human Trafficking in Malaysia

\section{References}

Braun, V., \& Clarke, V. (2006). Using Thematic Analysis In Psychology. Qualitative research in psychology, 3(2), 77-101.

Mack, N. (2005). Qualitative Research Methods : A Data Collector's Field Guide. North Carolina: Family Health International.

Eusof, N. M. (2016). Jenayah Pemerdagangan Orang Dan Penyeludupan Migran Di Malaysia : Perspektif Undang-Undang Dan Islam. (Tesis Sarjana). Akademi Pengajian Islam, Universiti Malaya.

Habibah, O. (Ed.). (2011). Pemerdagangan Manusia. Putrajaya: Jabatan Penerangan Malaysia Kementerian Komunikasi Dan Multimedia.

Patton, M. Q. (2015). Qualitative Research \& Evaluation Methods : Integrating Theory And Practice. Thousand Oaks, CA: Sage Pub.

Patton, M. Q. (1990). Qualitative Evaluation and Research Methods (Second Edition). Newbury Park, Calif.: Sage Pub.

Piaw, C. Y. (2006). Kaedah Penyelidikan (Edisi Pertama). Kuala Lumpur : McGraw Hill.

Richmond, J. C. (2017). The Root Cause of Trafficking is Traffickers. Diunduh dari https://www.traffickinginstitute.org/the-root-cause-of-trafficking-is-traffickers/

Samuni, N., \& Kanyo, N. I. (2013). Usaha Malaysia Dalam Membanteras Jenayah Pemerdagangan Orang: Satu Tinjauan. International Journal of Environment, Society and Space (IJESS), 1(1), 62-74. 
INTERNATIONAL JOURNAL OF ACADEMIC RESEARCH IN BUSINESS AND SOCIAL SCIENCES

Vol. 10, No. 3, March, 2020, E-ISSN: 2222-6990 @ 2020 HRMARS

Harian, S. (2019). Tiada Penamat Perangi Pemerdagangan Manusia. Sinar Harian Online. Diunduh dari https ://www .sinarharian .com.my /article /41628 /BERITA/Nasional/Tiada-penamatperangi-pemerdagangan-manusia

The Bali Process. (2015). Panduan Polisi Untuk Mengenalpasti Mangsa Pemerdagangan. Sathorn Bangkok, Thailand: The Bali Process.

U.S. Department of State. (2006). Trafficking in Persons Report 2006. Diunduh dari https://20092017.state.gov/j/tip/rls/tiprpt/2006/65989.htm Zikmund, W. G. (2013). Business Research Methods. Mason, $\mathrm{OH}$ : South-Western Cengage Learning.

United Nations. (2000). Protocol To Prevent, Suppress And Punish Trafficking In Persons, Especially Women And Children, Supplementing The United Nations Convention Against Transnational Organized Crime. Vienna: United Nations Office on Drugs and Crime, United Nations Convention against Transnational Organized Crime and the Protocols Thereto.

U.S. Department Of State. (2016). Trafficking in Persons Report 2016. Diunduh dari https://20092017.state.gov/documents/organization/243560.pdf

U.S. Department Of State. (2018). Trafficking in Persons Report 2018. Diunduh dari https://www.state.gov/j/tip/rls/tiprpt/index.htm

Yaakob, W. A. H. (Ed.). (2015). Pemerdagangan Manusia. Putrajaya: Jabatan Penerangan Malaysia Kementerian Komunikasi Dan Multimedia. 